Article

\title{
Framing Social Sustainability in Infrastructure Theory and Practice: A Review of Two Road Projects in Mexico from a Business and Human Rights Lens
}

\author{
Laura Treviño-Lozano
}

Sapiens Network, European Union's Horizon 2020 Research and Innovation Programme, University of Greenwich, London SE10 9LS, UK; 1.trevinolozano@greenwich.ac.uk

\begin{abstract}
While it has been more than 30 years since sustainability appeared in the development agenda, it remains a fashionable concept with an underdeveloped social dimension and no common understanding. In infrastructure, social sustainability has been neglected or limited to positive social impacts without considering negative social impacts linked to the prevention and redress of business-related human rights abuses on workers, end-users and communities. Through a literature review, this paper explores how sustainability is framed in theory, particularly its social dimension in the context of infrastructure. Across a qualitative analysis of a socially sustainable road projectNecaxa-and a socially unsustainable-Paso Expres-it further explores the elements that frame social sustainability in Mexican practice of road infrastructure, including the role that businesses and human rights play.
\end{abstract}

Keywords: socially sustainable infrastructure; business and human rights; road infrastructure; social sustainability; SDG12; Agenda 2030; UNGPs; guiding principles of business and human rights; human rights due diligence; operational-level grievance mechanisms

Citation: Treviño-Lozano, L. Framing Social Sustainability in Infrastructure Theory and Practice: A Review of Two Road Projects in Mexico from a Business and Human Rights Lens. Sustainability 2022, 14, 2369.

https://doi.org/10.3390/su14042369

Academic Editors: André Paixão,

Eduardo Fortunato and

Giovanni Leonardi

Received: 19 October 2021

Accepted: 19 January 2022

Published: 18 February 2022

Publisher's Note: MDPI stays neutral with regard to jurisdictional claims in published maps and institutional affiliations.

Copyright: (c) 2022 by the author. Licensee MDPI, Basel, Switzerland. This article is an open access article distributed under the terms and conditions of the Creative Commons Attribution (CC BY) license (https:// creativecommons.org/licenses/by/ $4.0 /)$.

\section{Introduction}

Sustainability appeared in the international development agenda in 1987, when the Brundtland report framed it as the ability to meet present needs without compromising future generations' ability to fulfil their own needs [1,2]. It was considered an environmental concern based on 'ecological principles and resource efficiency' [3-5]. The 1992 Earth Summit and 2002 World Summit for Sustainable Development advanced sustainable development by presenting its application in infrastructure through Agenda 21 for Sustainable Construction in Developing Countries. [6]. Further on, Agenda 2030 dedicated sustainable development goal (SDG) 9 to infrastructure, which is additionally linked directly or indirectly to delivering $72 \%$ of the 17 SDGs [7].

Infrastructure is a core pillar of development that, since the 1980s, together with the advent of sustainability, involved an increasing participation of businesses. The financial and technical limitations of states to cover infrastructure gaps, alongside neoliberal principles embedded in the Washington Consensus, constrained the intervention and regulation by Latin American states and encouraged the participation of 'more efficient' and 'financially capable' private actors in the design, construction, operation and maintenance of core infrastructure such as transport [8-14].

Sustainable infrastructure is defined as that 'planned, designed, constructed, operated and decommissioned in a manner that ensures economic and financial, social, environmental (including climate resilience) and institutional sustainability over the entire life cycle of the project' $[12,15]$. Infrastructure contracted by states and developed by businesses can impact economies, the environment and societies positively.

By contributing to one-tenth of the global GDP and creating 7\% of the world's employment, it can boost economies [16]. In 2017, the construction industry represented Mexico's 
fourth major economic sector contributing to $8 \%$ of its GDP and the third economic activity with more capacity to create employment entailing more than 6 million direct jobs [17]. Mexico spends from 15 to $20 \%$ of the Federation Expenses Budget in developing its infrastructure [18]. By mitigating carbon emissions and promoting the efficient use of resources, infrastructure can protect the environment and address climate change. Through providing essential services such as energy, water and sanitation, transport and telecommunications, infrastructure can enhance people's living standards and reduce poverty.

Conversely, infrastructure can also create negative social impacts on workers, endusers and communities' human rights during all phases of the project's lifecycle. Businessrelated human rights abuses related to the development of infrastructure were the major concern of the UN Working Group on Business and Human Rights during its visit to Mexico in 2016, and a key remark by the Special Rapporteur on Economic, Social and Environmental Rights in Latin America [19,20]. Yet, negative impacts linked to human rights abuse have been given little attention in the understanding of social sustainability [21-24].

Workers in supply chains are exposed to inadequate and unfair working conditions and accidents in the building industry, particularly in developing countries [25]. Besides, construction is a big contributor of child and forced labour. In Mexico, together with mining, it is the second biggest that accounts for $23.2 \%$ of underaged workers [26-36]. The construction sector consumes numerous raw materials such as natural stone, aggregates, sand gravel, gypsum and metallic minerals sourced through mining activities, which have a big environmental and social footprint $[37,38]$. Furthermore, communities continue to experience involuntary displacement, land grabbing, harassment and killing of their leaders and defenders when they oppose mega-infrastructure projects that interfere with their access to natural resources and violate free, prior and informed indigenous consultation [7,39-43].

As a response to business-related abuses, including those deriving from large-infrastructure projects, the UN Human Rights Council adopted in 2011 the Guiding Principles on Business and Human Rights: Implementing the United Nations "Protect, Respect and Remedy" (UNGPs) [44]. This framework sets a global standard of expected behaviour for states and enterprises. The UNGPs establish that states have a duty to protect human rights from businesses activities. More specifically, when states contract services and works, they have a purchasing power that can be leveraged over private suppliers to set high standards of compliance and create a demand for sustainability in markets $[45,46]$. On their part, businesses have the responsibility to respect human rights throughout their operations. This burden entails preventing abuses they may cause through human rights due diligence and redressing harm when produced through operational grievance mechanisms and collaboration with state-based grievance mechanisms.

While more than 30 years have passed since sustainability appeared in the international development agenda, its understanding in infrastructure projects continues to be unclear, focused only on environmental concerns without addressing the social dimension in a meaningful way. The 'social' dimension is the stagnant and underdeveloped component of sustainability [47-49]. Often social sustainability focuses on positive social impacts, but neglects negative social impacts. The latter are linked to the prevention and redress of business-related human rights abuses of workers, communities and end-users during the planning, construction and operation of infrastructure projects. Certainly, this loophole can jeopardize the sustainable outcome. This paper contributes to filling the human rights gap of social sustainability and to frame sustainability's social dimension in the context of road infrastructure by identifying the elements that have comprised this concept in practice and the role business and human rights have played.

\section{Research Design}

Through a literature review, this paper explores how sustainability, in the context of infrastructure, is framed in theory, bringing particular attention to its social dimension. Papers related to social sustainability, social or responsible public procurement and human rights abuses in the context of infrastructure were reviewed. Key elements in scholarly 
work that are related to social sustainability were identified to build a framework with a clearer definition of what social sustainability entails and the elements that are comprised within it.

Besides this, a qualitative research method approach was undertaken to analyse how these social sustainability elements look like in practice through two road infrastructure case studies, Necaxa and Paso-Expres. The selection criteria of these cases were their multiple similarities in the type of road infrastructure, the country of implementation, the total investment amount, the contracting authority and the nationality of the businesses involved in their construction, as well as their opposite social sustainability outcomes. While Necaxa was a project awarded as sustainable, Paso-Expres was the subject matter of a recommendation issued by the National Human Rights Commission due to human rights abuses that derived from its construction and operation. Their similar contexts and distinct social outcomes allow one to analyse the conditions under which social sustainability elements found in the literature review were applied or should have been applied in practice to enhance the socially sustainable outcome. Particularly, a project with a negative social outcome was required to be able to analyse the redress of human rights abuses, a key component of social sustainability. This empirical research and analysis help to define social sustainability and its main elements in practice in-depth and therefore contribute to framing a better understanding of the social sustainability of road infrastructure.

The qualitative research method involved the analysis of secondary sources from both projects, including contracts, concessions, an environmental impact assessment (EIA) and reports, as well as primary sources through interviews with eight experts. The selection criteria of interviewees were their direct or indirect involvement in the procurement process to develop the road projects or expert knowledge about them. Interviewees 1-4 were related to Necaxa and 5-8 to Paso-Expres.

Four open-ended questions were addressed to interviewees to identify elements that are considered part of social sustainability in both road infrastructure projects, with a particular focus on the prevention and redress of business-related human rights abuses: (1) How do you understand sustainability in the context of infrastructure? (2) How was sustainability understood, applied and weighted in this road infrastructure case study? (3) What role did corporate human rights due diligence play? This is the identification, mitigation, monitoring and disclosure of workers' and communities' human rights affectations by businesses, including the enforcement of labour standards in businesses' workers and supply chain. (4) What role did community engagement and local knowledge and grievance mechanisms play in the prevention and redress of human rights affectations? The questions were flexible to have space to further explore related topics the interviewee was best placed to talk about, and a particular focus was given to the role that human rights and businesses played in both projects. Interviewees' answers were coded and clustered based on their linkage with social sustainability elements found in the literature review. These elements were matched with the potential target group of people they were related to according to interviewees' narratives.

This project design is limited to findings from a low number of interviewees, a certain type of transport infrastructure and the social dimension of sustainability. While social sustainability walks hand in hand with environmental sustainability problems, the analysis of the latter is only examined in the extent to which it had a direct and clear relation to human living standards. In addition to interviews, the analysis is based on secondary sources. Therefore, it is constrained to individual perspectives, and important information could have been disregarded or poorly addressed. The results can be generalised to other road transport infrastructure projects in Mexico, but they might also be too ambitious for small road projects.

Finally, the analysis of this study is based on the UNGPs and aims to identify the compatibility and alignment of state and business actions, measures and plans with what the UNGPs call for, regardless of the terminology that is used. Particularly, because one of the analysed projects started and ended before the adoption of the UNGPs, so this represents another limitation to the research. Therefore, projects might include certain 
business and human rights considerations, such as operational-level grievance mechanisms or the right to access water, without using such terms. In that sense, the author identifies these concepts and provides a business and human rights language.

\section{Literature Review}

Sustainability is a popular concept that has gained attention in the development agenda in different sectors, including infrastructure [50]. However, there is no common understanding or standard definition for sustainability [51]. Critics highlight that the 'fuzziness' in this fashionable word permits anything to be acknowledged as sustainable and therefore 'allows business and development interests (and their government supporters) to claim they are in favour of sustainable development when actually they are the perpetrators of unsustainability', which has undervalued the concept [52]. In the construction sector, determining whether an infrastructure project is sustainable, and how and when to apply and weigh each of its components, is difficult [53], and measuring non-economic aspects of sustainability is often complex.

It is well-recognised that sustainability is underpinned by economic, environmental and social dimensions $[25,53,54]$. Yet, in the context of infrastructure, sustainability is still framed as a notion limited to environmental degradation and climate change. 'Green' infrastructure is frequently used interchangeably with 'sustainable' infrastructure [21,50,55-59]. The common focus of 'sustainable' infrastructure is on energy consumption, including fossil fuel utilisation in the case of transport infrastructure [60,61]. Kibert addresses sustainability in the extent to which construction projects reduce water and energy use, as well as emissions, underpinned by natural and industrial ecology [62]. Moreover, Green Building Systems' 'sustainable' goals are based on emission and water reduction, environmental protection, energy efficiency, environmentally harmful material elimination and resource conservation, but there are no social or human rights considerations [50]. The appearance of sustainability as a response to economic growth in detriment of the environment might explain the green influence on today's understanding of sustainability.

The narrowed environment-only frame of sustainability has neglected the social dimension, which is causing humans to fall behind in development [56,63-65]. Green infrastructure reflects a disarticulation of the three dimensions of sustainability in this sector because they are understood as independent rather than co-dependent variables, which hampers a comprehensive sustainable outcome. For example, only $7.5 \%$ of civil engineers in the US considered social and cultural factors as components of 'sustainable' construction [50]. Similarly, interviewees in Cambodia failed to establish the correlation between social drivers and sustainable construction [3].

Besides, the social dimension has not been defined with clarity and remains the 'least developed dimension of sustainability' [66-70]. Little attention has been given to framing it in a comprehensive way that includes human rights at its core. Social sustainability's dynamic and changing features in time and place have posed challenges to frame it in theory and implement it in practice [70-72].

In the context of infrastructure, social sustainability is often related to positive social impacts linked to poverty indexes such as the enhancement or improvement of employment (including job creation and better working conditions) [23,73-78], market inclusion of certain groups such as aboriginal-owned and black-owned businesses [66,76,77] and local supply $[79,80]$. Job creation and inclusion have been used by governments through public procurement to reinforce law provisions on human rights or go beyond them, demanding private suppliers to take actions that they otherwise would not take [81]. These variables target workers in infrastructure supply chains as rights-holders. The origin of these social procurement measures can be found in the US and the UK in the 19th century, to secure working hours and fair wages. Later on, they were used to favour labour conditions and tackle unemployment, as well as racial, gender and ethnic discrimination [77].

The positive social dimension of sustainable infrastructure goes beyond improving labour conditions and creating jobs, not only due to its wider potential, but also because 
there are other rights-holders at stake. Neighbouring communities of locations where infrastructure is physically installed, as well as end-users of infrastructure services, are all recipients of the project's impacts. Other social sustainability elements target these groups such as the enhancement of education, health $[3,23,53,66,74,82,83]$ and living standards $[67,84]$. Often, improving living standards in road infrastructure is narrowed to the construction of a pathway that allows individuals to commute in less time and cost. Yet, there are other important aspects within the notion of 'living conditions' such as the physical and economical accessibility to the transport service for everyone, including the poor, disabled and women $[69,70,85,86]$.

Despite the significance of negative social impacts, few authors acknowledge that they are core elements of 'social sustainability' [70,87]. An explicit focus of social sustainability on addressing negative social impacts through the prevention and redress of businessrelated human rights abuses has been neglected [3]. Indeed, human rights are not conceptualised as an impact nor are they integrated into the notion of social sustainability [88]. Certainly, poverty reduction through job creation, for example, is interconnected with the realisation of the human right to work, and both are essential conditions for the enjoyment of the right to development [89]. Yet, employment generation will not secure by itself that employees receive equal remuneration and minimum wages or that they work in safe and healthy conditions. Therefore, social sustainability should not be restricted to social positive impacts only, but should also include negative social impacts. [66,90].

The UNGPs shed light on why, who, how and when negative impacts on human rights should be tackled in a socially sustainable infrastructure delivered by private developers. This framework further establishes an additional burden for states to protect human rights abuses from businesses with whom they have a contractual relationship or a state-business nexus, including procurement to develop infrastructure. However, the UNGPs have had little impact in developing countries that require these rules to be enforced the most [91].

Businesses have the responsibility to prevent negative human rights impacts through human rights due diligence. The latter involves four key steps, involving (1) the assessment and identification of human rights adverse impacts that corporate activities may cause or contribute to; (2) the adoption of appropriate measures to address impact assessment findings; (3) effective follow-up of implemented measures; (4) and communication of how impacts were addressed [92]. Furthermore, businesses must redress human rights abuses through operational-level grievance mechanisms created and administered by them and cooperate with grievance mechanisms created and administered by the state. The UNGPs establish eight core features that such operational-level mechanisms should comply with, which include being legitimate, accessible, predictable, equitable, transparent, rightscompatible, a source of continuous learning and based on engagement and dialogue. Yet, the ways in which responsible business conduct can be implemented and enforced by States throughout the development of infrastructure, which often occurs with great participation of businesses, has not been comprehensively developed in theory and practice.

In sum, positive and negative spheres compose the social sustainability of infrastructure. The 'positive' sphere relates to the elements through which infrastructure 'creates benefits' for people, often related to poverty indexes such as job creation, living conditions and health and education, whereas the 'negative' sphere is connected to those elements through which infrastructure 'addresses harm' to people by preventing and redressing human rights abuses as seen in Table 1. Both spheres are strongly connected to both public and private parties that intervene in the design, execution and operation of projects, particularly business developers. 
Table 1. Core elements of social sustainability of road infrastructure projects in theory.

\begin{tabular}{|c|c|}
\hline Social Sustainability Spheres & Elements \\
\hline Positive & $\begin{array}{c}\text { Improvement of working conditions } \\
\text { Enhancement of living standards } \\
\text { Creation of local supply/job creation/social inclusion } \\
\text { Enhancement of health and education }\end{array}$ \\
\hline Negative & $\begin{array}{l}\text { Prevention of human rights abuses } \\
\text { Redress of human rights abuses }\end{array}$ \\
\hline
\end{tabular}

\section{Results}

\subsection{Road Projects Overview}

The highway Nuevo Necaxa-Avila Camacho (Necaxa) entailed the construction of $36.6 \mathrm{~km}$ of road connecting Puebla and Veracruz involving four-lane roads, six double tunnels and twelve bridges. It is a road section of a larger project connecting Mexico City with Tuxpan, one of the main ports of the country. It aimed to boost trade and reduce travel time from 5.3 to 2.5 hours [93]. The project involved positive and negative considerations to social sustainability and won the Infrastructure $360^{\circ}$ award given by the Inter-American Development Bank in coordination with Harvard University to outstanding sustainability practices in infrastructure investments in the region [93]. Necaxa is a 75-million-dollar project awarded by the Ministry of Communications and Transport (SCT) to a private consortium constituted by Mexican and Spanish companies [93]. The works started after July 2007, years before the adoption of the UNGPs, and finished in April 2012.

The Paso-Expres highway involved a six-lane addition to a high-speed motorway of four lanes connecting Mexico City and Cuernavaca, with a total length of $14.5 \mathrm{~km}$, and ten lanes. However, the project's design first considered a total of 8 lanes, which was modified during the procurement process to 10 lanes, without adapting the corresponding assessments like the Environmental Impact Assessment (EIA) [94]. It aimed to address road network saturation and promised low-maintenance rates and life durability of over forty years [94]. Paso-Expres was a 75-million-dollar project awarded by SCT to a consortium of two Spanish and Mexican companies. The works began in November 2014 and finished in April 2017, therefore after the adoption of the UNGPs. However, the Paso Expres collapsed three months after its opening. In consequence, the National Human Rights Commission opened an investigation and issued a recommendation to the SCT for violations against the human right to life of four people during the construction and operation of Paso-Expres [94].

\subsection{Positive Social Impacts Sphere of Social Sustainability}

\subsubsection{Improvement of Working Conditions}

Two interviewees stressed labour conditions and standards as important within the social sustainability of any infrastructure project. However, no decent work indicators such as equal salaries, minimum wage, trade unions, collective bargaining or working hours were mentioned by the interviewees as part of social sustainability. On the contrary, interviewee 8 mentioned 'there is no investigation [during the selection of the contractors] by the contracting authority on whether the company complies with paying decent salaries to their workers. There is no interest if they pay them well or badly'. The only interest is on whether contractors have enough workers and the technical capacity to perform the work.

\subsubsection{Enhancement of Living Standards}

In relation to the enhancement of the living standards of end users, all interviewees (except one) considered the positive social aspect of both projects to be related to benefits for transport users deriving from fulfilling their mobility needs and reducing their commuting time and costs. However, there is an economic domination of the concept because the social benefits are considered in the extent to which they can be quantified in monetary terms and represent economic savings and advantages. 
Interviewees 1-4 expressed Necaxa was beneficial to society and ultimately end users because it connected and enhanced the pathway of communication between two key cities in the country. The previous road was inefficient and dangerous due to many curves, heavy rains and fog that provoked multiple accidents, blocking traffic flow for hours. Interviewee 2 mentioned socio-economic assessments were undertaken to determine whether the project was 'socially profitable, this is that it benefits the society as a whole' because it reduces vehicular operation, maintenance and commuting costs and time.

Likewise, interviewees 5, 7 and 8 mentioned Paso-Expres was a project that produced social benefits because it addressed heavy traffic jams in that section of the road. During the holiday season, the road was saturated and limited the mobility of local and foreign flows going from Mexico City to Acapulco, a popular tourist destination. Interviewee 7 responded that Paso-Expres enhanced 'traffic flows' and 'travel time' 'so it seems it accomplished its aim'.

Additionally, Necaxa considered local communities as users, and their specific needs of transport were assessed and addressed. Economic and physical access to the transport service of locals was integrated into the project. An assessment was undertaken to determine which tranches of the road project from Mexico City to Tuxpan would involve a tariff and which ones would not, based on the travel patterns of low-income communities that undertook short-distance commutes. Interviewee 4 mentioned specific entries and exits were contemplated in the construction, so that local communities could have physical access the road.

In Necaxa, the improvement of human living standards was further linked to environmental sustainability. The resilience of nine communities to environmental impacts was enhanced through an agency-based approach. As a result of the concerns raised by the community of Teteloya, private developers increased local people's capacities to cope with environmental hazards such as floods by building a retention wall, as well as fires through donations of first aid kits, fire extinguishers and walkie talkies. Besides, during the construction of the road, hurricane Arlene hit locals living in Teteloloya. The affected community received a donation of 80 emergency food packages from Necaxa's private developers [93]

\subsubsection{Creation of Local Supply/Jobs/Social Inclusion}

Besides the enhancement of living conditions that derived from the project's better, easier and cheaper transportation, Necaxa worked to create a demand of local supply and to implement programmes to increase education and health conditions of their workers, which were ultimately locally recruited.

Interviewees 1, 2 and 4 mentioned private developers in Necaxa recruited local workers as far as possible and contracted a local supply of small materials or food such as sodas and lolly pops, thus creating direct and indirect employment that activated local economies and social inclusion in the market outside of the scope of construction. One of the interviewees mentioned that a food vendor everybody knew at the construction site was able to buy a plot of land thanks to the fixed income provided by the project's workers who bought his products for three continuous years.

Moreover, job opportunities in Necaxa were adapted to local values and culture and linked to the project's programmes to mitigate environmental impacts. Interviewee 1 said one day business personnel were having lunch with locals from the community of 'Cuaxicala' who described how previous generations used a certain type of tree to produce crafts, which disappeared. By learning this, the company included those trees in the reforestation programme, which also recovered a former income and lost livelihood.

\subsubsection{Enhancement of Health and Education}

In Necaxa, a vaccination programme was launched by private developers to address several diseases such as the flu virus, intestinal parasites, tetanus and influenza. A total of 221 workers and project staff benefited from the scheme [93]. 
A programme to improve workers' education was implemented through a partnership with the National Institute for Education of Adults, which enabled them to certify unskilled workers in primary and secondary levels of education [93]. Besides, interviewee 1 mentioned the Necaxa project not only needed non-skilled workers, but also a skilled labour force. So, a two-sided partnership-building relationship between businesses and local universities emerged to include local engineering students as interns to the project. Businesses had the need for a specialized workforce and universities were interested to provide professional training to their students. She further mentioned interns and local workers 'give another point of view, because only they know how things are handled there' in their own territory.

\subsection{Negative Social Impacts Sphere of Social Sustainability}

\subsubsection{Prevention of Human Rights Abuses}

More than half of the interviewees considered the acquisition of the rights of way was strongly linked to the social sustainability of both road projects. All road projects need land to be physically installed, which always involves land acquisition either by negotiation or by public expropriation. Some interviewees- 5,6 and 7-did not mention the rights of way as part of the social result of the road project. Others -3 and 8 -limited the project's negative social impacts to this aspect. The latter stressed 'the negative impact disappears when they [landowners] accept [the works] to be done with the corresponding payment [of their land]'.

In both case studies, the obtention of rights of way was based on informing landowners about the project and its benefits, as well as negotiating the price of their lands to be bought by SCT. Interestingly, none of the interviewees mentioned whether communities were informed about the potential negative impacts of the project to their livelihoods or their social, economic or cultural activities and the corresponding measures that businesses would undertake to mitigate or eliminate them when constructing and operating infrastructure.

In addition, in the Necaxa project, the acquisition of rights of way involved local engagement through local authorities so they could provide the input of the involved communities' specific needs to include them in the compensation of land acquisition. Interviewee 4 mentioned that SCT was aware that 'ejidatarios' or landowners are culturally entrenched to their lands, and these are essential sources of livelihood. Therefore, buying from them requires 'very intense work of social sensibility'.

Interviewee 4 further mentioned acquiring the rights of way needs to involve more actions than 'just buying their lands', even for a higher price. Rather, it must 'explore the communities' needs to understand the solutions and comprehensively address negative impacts. Some landowners expressed concerns about negative impacts that would result from selling their land, such as dividing their property and facing difficulties in fetching water or accessing their wells on the other side of the road. Thus, he stated it is not enough to listen to communities' needs in relation to their land in economic terms, but also in non-economic terms regarding education, health, tourism or mobility.

Besides, six interviewees related the prevention of human rights abuses to social sustainability. Paso-Expres limited the understanding of social negative impacts to the obtention of rights of way, disregarding the prevention of any other adverse impacts to communities, workers or supply chains. In contrast, Necaxa included the prevention of human rights abuses focused on communities and workers. Although Necaxa started before the UNGPs existence and therefore available information related to the project does not use UNGPs terms, the analysis is based on guiding provisions set within this framework for responsible business conduct. More specifically, UNGP17 on adopting human rights due diligence processes to assess any actual and potential adverse human rights impacts.

The legal framework didn't mandate to assess and mitigate other than environmental impacts through an EIA to develop road projects. Yet, Necaxa's EIA addressed identification and mitigation measures of some social adverse impacts against communities and workers but failed to address supply chains [95]. For example, an interviewee said the business 
contractor could subcontract 'but the responsibility and obligation with the contracting authority was only of the awarded company'.

The EIA does not explicitly mention human rights, but includes social impact identification and mitigation [95]. According to the concession contract, the EIA was undertaken by SCT because it was part of the obligations and risks the public entity assumed, and compliance to the EIA was established as a contractual obligation for private developers when conducting the works [96].

The first measure the EIA established was compliance with the applicable legal framework regarding noise limits for machinery and construction equipment, which reflects an alignment with UNGP 23. Private developers mitigated noise levels with noise-reducing equipment, and they were regularly monitored during construction. Noise pollution was also reduced by half. Secondly, a plan to restore local pathways was established to mitigate disruption to people's livelihoods and mobility patters of pedestrians, vehicles and livestock. As a result 'the Locality of Plan de Ayala received improved roads [by private constructors] while Teteloloya also secured paths across the highway to connect to the agricultural fields and other localities' [93].

Third, Necaxa's EIA provided adequate signage to prevent accidents for workers and neighbouring communities. Developers implemented 'traffic-calming and evacuation route signage in and around the project sites and the local communities' [93]. Measures identified within the EIA during the planning stage were adapted by businesses during the construction phase to address local concerns, and to include local knowledge through continuous engagement with communities.

The prevention of risks of abuse against end-users, neighbouring communities and workers' rights was stressed by interviewees as a relevant and missing aspect across the life cycle of Paso-Expres. Human rights abuses derived from private contractors' activities. Harms included damages to water pipelines that affected diverse communities in their access to drinking water for several days; poor water management that caused flooding of the sewage of neighbouring communities and contamination of irrigation channels used for crops and nursery [97]; poor waste management and road-blocking without prior notice that affected local mobility. Notwithstanding interviewee 8 said businesses gave notice of road-blocking to people, which was held 'in sections' to avoid impacts to local traffic.

In addition, modifications to old walking pathways alongside inadequate signage during construction became dangerous to cross from one side of the road to the other for pedestrians and to circulate through that road section of Paso-Expres for vehicles according to the Human Rights Commission's investigation. As a result, two pedestrians walking through the pathways fell and died, and 130 people were killed in over 100 car accidents. People started to call Paso-Expres 'The Death Passage' [94,97].

Moreover, an EIA exception was granted in October 2014 by the Ministry of the Environment and Natural Resources. However, such an exception was not based on the final 10-lane design, but on the previous design of 8 lanes. The SCT undertook consultations on whether there were impacts to water crossings a year after the works started. This reflects an important weakness in the technical planning and design of the project. Before the works were finished, the motorway already presented scours and flows.

The contracting authority and business contractors were aware that pipelines would not resist water flows and would eventually break. Yet, no action was taken by either, and three months after the motorway started to operate, it collapsed and caused the death of two more people [94].

\subsubsection{Redress of Human Rights Abuses}

Five interviewees related the redress of human rights impacts to the social sustainability of both road projects (Table 2). In Necaxa, the redress of human rights impacts took place through operational-level or corporate grievance mechanisms. Interviewee 1 mentioned Necaxa's business contractors had a Handbook that established grievance mechanisms administered by the company to address concerns related and unrelated to the 
project. For example, complaints regarding trucks transit were addressed by the company through verification on whether the trucks were circulating through the established areas and rectified immediately in case they did not.

Table 2. Core elements of social sustainability of road infrastructure projects in practice.

\begin{tabular}{ccc}
\hline $\begin{array}{c}\text { Social Sustainability Spheres in Road } \\
\text { Infrastructure Projects }\end{array}$ & Elements & Right Holders \\
\hline Positive & Improvement of working conditions & Workers \\
\cline { 2 - 3 } & Enhancement of living standards & Neighbouring \\
\cline { 2 - 3 } & $\begin{array}{c}\text { Creation of local supply/job } \\
\text { creation / social inclusion } \\
\text { Enhancement of health and education }\end{array}$ & $\begin{array}{c}\text { Neighbouring } \\
\text { communities and workers }\end{array}$ \\
\hline Negative & $\begin{array}{c}\text { Prevention of human rights abuses } \\
\text { Redress of human rights abuses }\end{array}$ & $\begin{array}{c}\text { Workers, } \\
\text { neighbouring } \\
\text { and end users }\end{array}$ \\
\hline
\end{tabular}

Other claims addressed through this mechanism were unrelated to the project's works. For example, a complaint regarding land impacts was raised. After investigating, the contractors found these affectations were not caused by their road-related activities, but rather by the works of a simultaneous pipeline that was in construction by another company nearby. Necaxa's private developers provided community support by channelling the affected people with the corresponding enterprises of the other project. Likewise, communities filed requests for support on specific issues, for example to replace a weakened pipeline or lend a trunk for the patronal feast. The company assessed the possibility to support, usually through in-kind support with its own materials or human resources, rather than money according to interviewee 1 .

The operational-level grievance mechanism complied with several criteria established by the UNGPs according to interview findings. It was legitimate because stakeholders trusted them. It was accessible and based on engagement and dialogue because all stakeholder groups knew it existed. Moreover, the ways to access the mechanism were defined on an ongoing basis by local people. Interviewee 1 mentioned people approached the company's personnel directly or left written complaints in the company's facilities located in the middle of the project working site. Private developers did not establish a 'front desk' to exclusively address these issues, but rather left locals to determine how to approach them. Locals knew who the project leaders were because someone from their family or community worked on the project and identified where the business offices were located.

In contrast, businesses' operational-level grievance mechanisms and collaboration with state-based mechanisms were narrated by interviewees as a missing element of the social sustainability notion in the Paso-Expres project. Interviewee 5 said there was a 'divorce between the businesses and the community'; businesses 'had deaf ears' to individual and collective impacts. 'If the company had implemented these mechanisms, it is very clear that it would have avoided many [social] problems'. For example, it was well documented that constructors did not pay for nor repair damages to pipelines, which limited access to water for multiple neighbourhoods for several days. Rather, it was solved by the municipality by purchasing provisional waterpipes, which increased the project's budget [94]. Interviewees 6 and 7 coincided redress was needed for social sustainability and challenged the notion it was appropriately addressed, including for the people who died in the car accident. Notably, from interviewee 8's point of view, redress to the project's social impacts was fulfilled by paying the agreed amounts to landowners to buy their lands during the purchase of the rights of way. 
Moreover, a complaint regarding the death of two people in the car accident was filed before the National Human Rights Commission who requested for the involved businesses to provide records and information, but they refused to collaborate, hampering the grievance process and remediation for victims [94].

\section{Discussion}

The elements found in the literature review as part of the positive sphere of social sustainability were found throughout the analysis of both case studies. First, the improvement of working conditions was related to the social sustainability notion; however, it was not implemented in any of the two projects. Workers in the procurement of infrastructure are understood as commodities; only relevant inasmuch as they have the skills to perform the works, regardless of the working conditions they have agreed on with their employers.

Second, the enhancement of living standards was also an element of social sustainability of road infrastructure that goes beyond trade and commuting with less time and cost. Economic and physical accessibility of local people to road projects are core features of the right to an adequate standard of living, particularly "adequate basic infrastructure" at "a reasonable cost" [96]. Moreover, this second element is a means through which social sustainability can be reconciled with environmental sustainability in infrastructure projects. In the Necaxa case, the improvement of locals' living standards was strongly connected with the environmental risk management such as the reforestation programme and with the improvement of people's resilience to environmental hazards such as floods through a wall construction, hurricanes through emergency packages of food and fires through tools such as walkie talkies and fire extinguishers.

Third, the creation of local supply is an element that could entail not only direct employment through the integration of local people into the construction of projects but also indirect employment through creating a demand for supplies such as food and beverages that also benefit local communities. Direct and indirect employment impact their social inclusion in the market, and can also boost local economies.

Fourth, the enhancement of health and education was targeted locally with a long-term poverty alleviation vision, for example to provide local unskilled workers with higher levels of education or training young local engineers in order to provide better labour opportunities, even after the construction of the project was over.

Furthermore, two elements of the negative sphere of social sustainability were also found in both case studies. Fifth, the prevention of human rights abuses as an element of social sustainability was linked to the acquisition of the rights of way. The latter entails not only fair trade, but also identification and mitigation of other negative impacts that the acquisition of land might entail in the economic, cultural and social activities to the owners and their families. Yet, this fifth element is not constrained to landowners only. It is also connected to preventing human rights abuses against other right holders such as workers, neighbouring communities and end users. Environmental and social impact assessments were strongly related to a socially sustainable outcome.

Regarding the first two steps of human rights due diligence, Necaxa's EIA included identification and mitigation to adverse social impacts neighbouring communities, end users and workers. Participation of stakeholders is key in human rights due diligence process. Notably, a certain degree of participation of some of these groups, like local communities, in the implemented measures to mitigate social adverse impacts was observed. Yet, there was not enough information deriving from the EIA or interviews to determine whether all groups were considered as right-holders and as active agents in the design and implementation of EIA. Neither the contexts under which participation took place, for example, if non-discrimination and equality was a principle governing consultations or whose voices were considered. Besides the EIA was not based on internationally recognized human rights standards and principles. Although identified social risks can be related, for example, to the right to an adequate housing, there was no human rights language. 
Furthermore, the EIA did not include the third step related to follow-up of the effectivity of the mitigating measures with indicators, nor the fourth step of communicating the entire process, as the UNGPs call for. Accountability, transparency and access to information are essential to a human rights due diligence process. Particularly, tracking business responses and communicating how impacts are addressed to relevant stakeholders.

The lack of prevention of human rights abuses through adequate risk management processes in Paso-Expres was referred to as a big contributor to the unsustainable outcome and human rights violations, which strengthens its relevance as a core element of social sustainability. Furthermore, Paso-Expres particularly reflected the interdependence between environment and social sustainability because the absence of environmental risk management of water crossings in the pipelines led to the collapse of the project that resulted in the violation to the right to life of two people and to access water and sanitation of an entire community.

Sixth, the redress of human rights abuses through operational grievance mechanisms as well as business collaboration with state-based grievance mechanisms were also related with social sustainability. The way in which the operational grievance mechanism operated in the field in the Necaxa case contributes to the understanding of UNGPs' Pilar III in the context of infrastructure. The operational grievance mechanism was not only used to redress as the framework calls for, but also to provide information of the project and address other concerns raised by the community, which built trust between stakeholders. Therefore, the understanding and implementation of non-state-based grievance mechanisms in complex contexts such as developing large-infrastructure projects could encompass much more than what the UNPGs suggest. However, locals determining how to approach grievance mechanisms needs further research to analyse whether this scope and approach provided enough predictability and transparency, as well as the ways in which it secured stakeholders' feedback to identify barriers and improve the mechanism to prevent future harms in the future.

Within Pilar III, the UNGPs clearly set the important role that National Human Rights Institutions have to redress victims. Businesses should not only implement effective operational-level grievance mechanisms, but also participate in state-based judicial and non-judicial mechanisms. This responsibility includes not only avoiding placing barriers for effective remediation these mechanisms can provide to victims, but also actively collaborating with them through all their possible means.

Key aspects of social sustainability element implementation both in the negative and positive spheres were agency-based and cultural-based approaches in practice. In particular, businesses' engagement with local communities was identified, for example to improve resilience to environmental hazards, mitigate social negative impacts deriving from the acquisition of rights of way or the implementation of operational grievance mechanisms. Besides, the application of social sustainability elements in Necaxa further benefited companies. By recruiting locally, they lowered the cost of posting workers to the construction site from other parts of the country, gained local knowledge to the project and facilitated its social acceptation because a sense of community belonging to the project was created. Further investigation is needed to assess the social sustainability elements with indicators that enable the measurement of social impacts in communities, end users and workers, particularly because this analysis is restricted to secondary sources that might not reflect the reality of all impacted stakeholders.

\section{Conclusions}

Sustainability has no common understanding or standard definition of what it means, which makes its implementation problematic. In the context of infrastructure, it is often framed as a green-only concept that moves the environment forward but leaves people behind. The 'social' aspect is the underdeveloped dimension of sustainability with an unclear framework and a big human rights gap. 
Social sustainability in road infrastructure can entail a positive social impact sphere directed to 'create benefit', whose elements are improving employment conditions, enhancing human living standards, creating local supply demand, job creation and social inclusion as well as improving health and education. It also entails a negative social impact sphere focused on 'addressing harm', whose elements are preventing and redressing human rights abuses deriving from the activities of private developers of infrastructure.

This paper contributes by framing sustainability as a concept that goes beyond environmental concerns and by including human rights as a core component of social sustainability. The identification of the elements that could shape social sustainability in road infrastructure projects through a positive and negative impact approach also adds value to frame and understand this notion in more comprehensive ways. Moreover, it also presents the ways in which social sustainability's elements reconcile with the environment. The focus on the negative impact provides a space for human rights to fit within social sustainability and integrates both concepts, so far developed separately, into a single language.

Funding: This research has received funding from the European Union's Horizon 2020 research and innovation programme under the Marie Skłodowska-Curie grant agreement No 956696.

Institutional Review Board Statement: Interviews were conducted under the London School of Economics' Research Ethics Policy and Procedures and Informed consent guideline.

Informed Consent Statement: Informed consent was obtained from all subjects involved in the study.

Data Availability Statement: Data can be provided under request.

Acknowledgments: I would like to acknowledge interviewees, reviewers and scholars that participated in this research.

Conflicts of Interest: The author declares no conflict of interest. The funders had no role in the design of the study; in the collection, analyses, or interpretation of data; in the writing of the manuscript, or in the decision to publish the results.

\section{References}

1. World Commission on Environment and Development, Our Common Future; Oxford University Press: New York, NY, USA, 1987.

2. Kates, R.W.; Parris, T.M.; Leiserowitz, A.A. What Is Sustainable Development? Goals, Indicators, Values, and Practice. Environment 2005, 47, 8-21. [CrossRef]

3. Durdyev, S.; Zavadskas, E.K.; Thurnell, D.; Banaitis, A.; Ihtiyar, A. Sustainable Construction Industry in Cambodia: Awareness, Drivers and Barriers. Sustainability 2018, 10, 392. [CrossRef]

4. Kibert, C.J. Sustainable Construction. In Proceedings of the First International Conference of CIB TG 16, Tampa, FL, USA, 6-9 November 1994; Center for Construction and Environment, M.E. Rinker Sr. School of Building Construction, College of Architecure, University of Florida: Gainesville, FL, USA, 1994.

5. Kibert, C.J. The next Generation of Sustainable Construction. Build. Res. Inf. 2007, 35, 595-601. [CrossRef]

6. Du Plessis, C. Agenda 21 for Sustainable Construction in Developing Countries. CSIR Rep. BOU E 2002, 204, $2-5$.

7. Thacker, S.; Adshead, D.; Fay, M.; Hallegatte, S.; Harvey, M.; Meller, H.; O’Regan, N.; Rozenberg, J.; Watkins, G.; Hal, J.W. Infrastructure for Sustainable Development. Nat. Sustain. 2019, 2, 324-331. [CrossRef]

8. Putzel, J. The "Populist" Right Challenge to Neoliberalism: Social Policy between a Rock and a Hard Place. Dev. Change 2020, 51, 418-441. [CrossRef]

9. Mkandawire, T. Social Policy in a Development Context: Introduction. In Social Policy in a Development Context; Mkandawire, T., Macmillan, P., Eds.; ProQuest: Basingstoke, UK, 2004; pp. 1-34.

10. Hanlon, J.; Barrientos, A.; Hulme, D. Just Give Money to the Poor; Kumarian Press: Boulder, CO, USA, 2010; ISBN 9781565493339.

11. Williamson, J. The Strange History of the Washington Consensus. J. Post Keynes. Econ. 2004, 27, 195-206.

12. Bhattacharya, A.; Contreras Casado, C.; Jeong, M.; Amin, A.-L.; Watkins, G.; Silva Zuniga, M. Attributes and Framewokr for Sustainable Infrastructure; Inter-American Development Bank: Washington, DC, USA, 2019.

13. Treviño-Moreno, F.J. Asociaciones Público Privadas, 2nd ed.; Porrua: Mexico City, Mexico, 2020; ISBN 9786070933547.

14. Lenferink, S.; Tillema, T.; Arts, J. Towards Sustainable Infrastructure Development through Integrated Contracts: Experiences with Inclusiveness in Dutch Infrastructure Projects. Int. J. Proj. Manag. 2013, 31, 615-627. [CrossRef]

15. She, Y.; Shen, L.; Jiao, L.; Zuo, J.; Tam, V.W.Y.; Yan, H. Constraints to Achieve Infrastructure Sustainability for Mountainous Townships in China. Habitat Int. 2018, 73, 65-78. [CrossRef]

16. Djokoto, S.D.; Dadzie, J.; Ohemeng-Ababio, E. Barriers to Sustainable Construction in the Ghanaian Construction Industry: Consultants Perspectives. J. Sustain. Dev. 2014, 7, 134-143. [CrossRef] 
17. Centro de Estudios Económicos del Sector de la Construcción. Situación Actual y Perspectivas de La Industria de La Construcción En México; Centro de Estudios Económicos del Sector de la Construcción (CEESCO): Ciudad de Mexico, Mexico, 2019.

18. Auditoría Superior de la Federación. Problemática General En Materia de Obra Pública. 2012. Available online: https: //www.asf.gob.mx/uploads/61_Publicaciones_tecnicas/Separata_ObraPublica.pdf (accessed on 19 April 2020).

19. García Muñoz, S. Informe Empresas y Derechos Humanos: Estándares Interamericanos; Relatoría Especial sobre Derechos Económicos, Sociaales, Culturales y Ambientales REDESCA; Comisión Interamericana de Derechos Humanos: Washington, DC, USA, 2019 ; p. 211.

20. Consejo de Derechos Humanos. Informe Del Grupo de Trabajo Sobre La Cuestión de Los Derechos Humanos y Las Empresas Transnacionales y Otras Empresas Acerca de Su Misión a México; Consejo de Derechos Humanos: Washington, DC, USA, 2017; pp. 1-23.

21. Son, H.; Kim, C.; Chong, W.K.; Chou, J. Implementing Sustainable Development in the Construction Industry: Constructors' Perspectives in the US and Korea. Sustain. Dev. 2011, 19, 337-347. [CrossRef]

22. Peter, D.; Michael, H.; Teresa, P.; Michael, P. Evaluating Design-Build-Operate-Maintain Delivery as a Tool for Sustainability. Constr. Res. Congr. 2005, 2020, 1-10.

23. Rwelamila, P.D.; Talukhaba, A.A.; Ngowi, A.B. Project Procurement Systems in the Attainment of Sustainable Construction. Sustain. Dev. 2000, 8, 39-50. [CrossRef]

24. Martin-Ortega, O.; Methven O'Brien, C. Public Procurement and Human Rights: Opportunities, Risks and Dilemmas for the State as Buyer; Edward Elgar: Cheltenham, UK; Northampton, MA, USA, 2019; ISBN 9781788116305.

25. Shafii, F.; Arman Ali, Z.; Othman, M.Z. Achieving Sustainable Construction in the Developing Countries Southeast Asia. In Proceedings of the 6th Asia-Pacific Structural Engineering and Construction Conference (APSEC 2006), Kuala Lumpur, Malaysia, 5-6 September 2006.

26. Bronner, U.; Reikersdorfer, C. Urban Nomads Building Shanghai; Transcript: Bielefeld, Germany, 2016; ISBN 978-3-8394-3344-7.

27. Wells, J. The Construction Industry in Twenty-First Century: Its Image, Employment Prospects and Skill Requirements; International Labour Organisation: Geneva, Switzerland, 2001.

28. Rashid, A.; Aziz, A. Bangladeshi Migrant Workers in Malaysia's Construction Sector. Asia-Pac. Popul. J. 2001, 16, 3-22. [CrossRef]

29. Bhukuth, A. Child Labour and Debt Bondage: A Case Study of Brick Kiln Workers in Southeast India. J. Asian Afr. Stud. 2005, 40, 287-302. [CrossRef]

30. Schmelkes, S.; Ramirez, N.; Nesis, F. El Trabajo Infantil y El Derecho a La Educación En México; Ediciones Culturales Paidos: Ciudad de Mexico, Mexico, 2014; ISBN 978-607-9377-19-9.

31. Juarez, M.; Navarrete, E.L. El Entorno Familiar y El Trabajo de Niñas y Niños de 5 a 11 Años. México En Dos Momentos: 2007 y 2013. Pap. Población 2016, 22, 43-72.

32. Kiran, U.; Singh, S. Body Discomfort Analysis among Child Labour Working in Various Unorganized Sectors. Int. J. Humanit. Soc. Sci. Invent. 2013, 2, 20-23.

33. International Programme on the Elimination of Child Labour. Children in Hazardous Work: What We Know, What We Need to Do; International Labour Organization: Geneva, Switzerland, 2011; ISBN 9789221249184.

34. El Economista. Trabajo Infantil En México; El Economista: Ciudad de Mexico, Mexico, 2019.

35. El Pulso Laboral. Asciende a 3.2 Millones El Trabajo Infantil En México; El Pulso Laboral: Ciudad de Mexico, Mexico, 2019.

36. INEGI. Niños Que Trabajan. 2019. Available online: https://cuentame.inegi.org.mx/poblacion/ninos.aspx?tema=P (accessed on 19 April 2020).

37. ILO. Construction Sector. Available online: https://www.ilo.org/global/industries-and-sectors/construction/lang--en/index. htm (accessed on 19 April 2020).

38. Azapagic, A. Developing a Framework for Sustainable Development Indicators for the Mining and Minerals Industry. J. Clean Prod. 2004, 12, 639-662. [CrossRef]

39. Zoomers, A. Globalisation and the Foreignisation of Space: Seven Processes Driving the Current Global Land Grab. J. Peasant. Stud. 2010, 37, 429-447. [CrossRef]

40. Stavenhagen, R. Los Pueblos Indígenas y Sus Derechos: Informes Temáticos Del Relator Especial Sobre La Situación de Los Derechos Humanos y Las Libertades Fundamentales de Los Pueblos Indígenas Del Consejo de Derechos Humanos de La Organizaión de Las Naciones Unidas; UNESCO Office: Mexico City, Mexico, 2008; ISBN 9789295068001.

41. Pskowski, M. In Mexico, Cheap Gas Wins: Promises of Consultation Are Not Enough for Indigenous Communities in the Path of Pipeline Construction in Mexico, an Important Market for the Texas Shale Fields. NACLA Rep. Am. 2020, 52, 131-136. [CrossRef]

42. Birss, M. Criminalizing Environmental Activism. NACLA Rep. Am. 2017, 49, 315-322. [CrossRef]

43. Hallam, K. Environmental Defenders: Murdered, Missing and at Risk. Soc. Lawyer 2017, 75, 40-43. [CrossRef]

44. United Nations General Assembly. Human Rights and Transnational Corporations and Other Business Enterprises. 2011. A/HRC/RES/17/4. Available online: https://www.right-docs.org/doc/a-hrc-res-17-4/ (accessed on 19 April 2020).

45. Methven O'Brien, C.; Martin-Ortega, O. The Role of State as Buyer under UN Guiding Principle 6. Policy Paper 4; University of Greenwich, Business Human Rights and Environment Research: London, UK, 2017.

46. Martin-Ortega, O. Public Procurement as a Tool for the Protection and Promotion of Human Rights: A Study of Collaboration, Due Diligence and Leverage in the Electronics Industry. Bus. Hum. Rights J. 2018, 3, 75-95. [CrossRef]

47. Brammer, S.; Walker, H. Sustainable Procurement in the United Kingdom Public Sector. Supply Chain Manag. $2009,14,128-137$.

48. Bernal, R.; San-Jose, L.; Retolaza, J.L. Improvement Actions for a More Social and Sustainable Public Procurement: A Delphi Analysis. Sustainability 2019, 11, 4069. [CrossRef] 
49. Halonen, K.M. Is Public Procurement Fit for Reaching Sustainability Goals? A Law and Economics Approach to Green Public Procurement. Maastricht J. Eur. Comp. Law 2021, 28, 535-555. [CrossRef]

50. Chong, W.K.; Kumar, S.; Haas, C.T.; Beheiry, S.M.; Coplen, L.; Oey, M. Understanding and Interpreting Baseline Perceptions of Sustainability in Construction among Civil Engineers in the United States. J. Manag. Eng. 2009, 25, 143-154. [CrossRef]

51. Robinson, N. What Is Sustainable Infrastructure? Tunnels \& Tunnelling International. 2015. Available online: https: //publications.iadb.org/publications/english/document/What_is_Sustainable_Infrastructure_A_Framework_to_Guide_ Sustainability_Across_the_Project_Cycle.pdf (accessed on 19 April 2020).

52. Jacobs, M. Sustainable Development as a Contested Concept. In Fairness and Futurity: Essays on Environmental Sustainability and Social Justice; Dobson, A., Ed.; Oxford University Press: Oxford, UK, 1999; pp. 21-45. ISBN 9780198294894.

53. Slaper, T.; Hall, T. The Triple Bottom Line: What Is It and How Does It Work? Indiana Bus. Rev. 2011, 86, 4-8.

54. Elkington, J. Cannibals with Forks: The Triple Bottom Line of 21st Century Business; New Society Publishers: Gabriola Island, BC, Canada; Stony Creek, CT, Canada, 1998.

55. Thomé, A.M.T.; Ceryno, P.S.; Scavarda, A.; Remmen, A. Sustainable Infrastructure: A Review and a Research Agenda. J. Environ. Manag. 2016, 184, 143-156. [CrossRef]

56. Sodagar, B.; Fieldson, R. Towards a Sustainable Construction Practice. Constr. Inf. Q. 2007, 10, 101-108.

57. Serpell, A.; Kort, J.; Vera, S. Awareness, Actions, Drivers and Barriers of Sustainable Construction in Chile. Technol. Econ. Dev. Econ. 2013, 19, 272-288. [CrossRef]

58. Osman, W.; Udin, Z.; Salleh, D. Adoption Level of Sustainable Construction Practices: A Study on Malaysia's Construction Stakeholders. J. Southeast Asian Res. 2012, 2012, 270273. [CrossRef]

59. Alsanad, S. Awareness, Drivers, Actions, and Barriers of Sustainable Construction in Kuwait. Procedia Eng. 2015, 118, 969-983. [CrossRef]

60. Ortiz, O.; Castells, F.; Sonnemann, G. Sustainability in the Construction Industry: A Review of Recent Developments Based on LCA. Constr. Build. Mater. 2009, 23, 28-39. [CrossRef]

61. Reisi, M.; Sabri, S.; Agunbiade, M.; Rajabifard, A.; Chen, Y.; Kalantari, M.; Keshtiarast, A.; Li, Y. Transport Sustainability Indicators for an Enhanced Urban Analytics Data Infrastructure. Sustain. Cities Soc. 2020, 59, 102095. [CrossRef]

62. Kibert, C.J.; Sendzimir, J.; Guy, B. Construction Ecology and Metabolism: Natural System Analogues for a Sustainable Built Environment. Constr. Manag. Econ. 2000, 18, 903-916. [CrossRef]

63. Munyasya, B.M.; Chileshe, N. Towards Sustainable Infrastructure Development: Drivers, Barriers, Strategies, and Coping Mechanisms. Sustainability 2018, 10, 4341. [CrossRef]

64. Contreras Casado, C. Sustainable Infrastructure in a Post Covid Era, Italian Institute for Political Studies. 2020. Available online: https://www.ispionline.it/en/pubblicazione/sustainable-infrastructure-post-covid-era-26585 (accessed on 22 April 2020).

65. Zhou, L.; Lowe, D. Economic Principles of Sustainable Construction. In Proceedings of the Second International Conference on Construction in the 21st Century, Hong Kong, China, 10-12 December 2003.

66. Sierra, L.A.; Yepes, V.; Pellicer, E. A Review of Multi-Criteria Assessment of the Social Sustainability of Infrastructures. J. Clean. Prod. 2018, 187, 496-513. [CrossRef]

67. Diaz-Sarachaga, J.M.; Jato-Espino, D.; Alsulami, B.; Castro-Fresno, D. Evaluation of Existing Sustainable Infrastructure Rating Systems for Their Application in Developing Countries. Ecol. Indic. 2016, 71, 491-502. [CrossRef]

68. Missimer, M.; Robèrt, K.-H.; Broman, G. A Strategic Approach to Social Sustainability-Part 1: Exploring the Social System. J. Clean. Prod. 2017, 140, 32-41. [CrossRef]

69. Cuthill, M. Strengthening the "social" in Sustainable Development: Developing a Conceptual Framework for Social Sustainability in a Rapid Urban Growth Region in Australia. Sustain. Dev. 2010, 18, 362-373. [CrossRef]

70. Dempsey, N.; Bramley, G.; Power, S.; Brown, C. The Social Dimension of Sustainable Development: Defining Urban Social Sustainability. Sustain. Dev. 2011, 19, 289-300. [CrossRef]

71. Karami, S.; Karami, E.; Buys, L.; Drogemuller, R. System Dynamic Simulation: A New Method in Social Impact Assessment (SIA). Environ. Impact Assess. Rev. 2017, 62, 25-34. [CrossRef]

72. Hassan, S.; Antunes, L.; Pavón, J. Mentat: A Data-Driven Agent-Based Simulation of Social Values Evolution. Multi-Agent-Based Simul. X 2010, 5683, 135-146. [CrossRef]

73. Sourani, A.; Sohail, M. Barriers to Addressing Sustainable Construction in Public Procurement Strategies. Proc. Inst. Civ.Eng. Eng. Sustain. 2011, 164, 229-237. [CrossRef]

74. Islam, M.; Murad, M.W.; McMurray, A.J.; Abalala, T.S. Aspects of Sustainable Procurement Practices by Public and Private Organisations in Saudi Arabia: An Empirical Study. Int. J. Sustain. Dev. World Ecol. 2017, 24, 289-303. [CrossRef]

75. Ogunsanya, O.A.; Aigbavboa, C.O.; Thwala, D.W.; Edwards, D.J. Barriers to Sustainable Procurement in the Nigerian Construction Industry: An Exploratory Factor Analysis. Int. J. Constr. Manag. 2019, 2019, 1658697. [CrossRef]

76. Brammer, S.; Walker, H. Sustainable Procurement in the Public Sector: An International Comparative Study. Int. J. Oper. Prod. Manag. 2011, 31, 452-476. [CrossRef]

77. Mccrudden, C. Using Public Procurement to Achieve Social Outcomes. Nat. Resour. Forum 2004, 28, 257-267. [CrossRef]

78. McMurray, A.J.; Islam, M.M.; Siwar, C.; Fien, J. Sustainable Procurement in Malaysian Organizations: Practices, Barriers and Opportunities. J. Purch. Supply Manag. 2014, 20, 195-207. [CrossRef] 
79. Adjei-Bamfo, P.; Maloreh-Nyamekye, T. The "Baby Steps" in Mainstreaming Sustainable Public Procurement in Ghana: A "Double-Agency" Perspective. J. Public Aff. 2019, 19, 458. [CrossRef]

80. Pocock, J.; Steckler, C.; Hanzalova, B. Improving Socially Sustainable Design and Construction in Developing Countries. Procedia Eng. 2016, 145, 288-295. [CrossRef]

81. McCrudden, C. Buying Social Justice: Equality, Government Procurement, and Legal Change; Oxford Press: Oxford, UK, 2007.

82. Vanegas, J.A.; Pearce, A.R. Drivers for Change: An Organizational Perspective on Sustainable Construction. In Proceedings of the Construction Congress VI: Building Together for a Better Tomorrow in an Increasingly Complex, Orlando, FL, USA, 20-22 February 2000; pp. 406-415.

83. Deakin, E. Sustainable Development and Sustainable Transportation: Strategies for Economic Prosperity, Environmental Quality, and Equity; UC Berkeley, Institute of Urban and Regional Development: Berkley, CA, USA, 2001.

84. Adshead, D.; Thacker, S.; Fuldauer, L.I.; Hall, J.W. Delivering on the Sustainable Development Goals through Long-Term Infrastructure Planning. Glob. Environ. Chang. 2019, 59, 101975. [CrossRef]

85. Marsden, G.; Kimble, M.; Nellthorp, J.; Kelly, C. Sustainability Assessment: The Definition Deficit. Int. J. Sustain. Transp. 2010, 4, 189-211. [CrossRef]

86. McKenzie, S. Social Sustainability: Towards Some Definitions. 2004. Available online: https://www.semanticscholar.org/paper/ Social-sustainability\%3A-towards-some-definitions-Mckenzie/7a7ec41a3d0c0fb4f9099db456b32166b25275c9\#citing-papers (accessed on 19 April 2020).

87. Islam, M.; Siwar, C. A Comparative Study of Public Sector Sustainable Procurement Practices, Opportunities and Barriers. Int. Rev. Bus. Res. Pap. 2013, 9, 62-84.

88. Vanclay, F. Conceptualising Social Impacts. Environ. Impact Assess. Rev. 2002, 22, 183-211. [CrossRef]

89. Salomon, M. Global Responsibility for Human Rights: World Poverty and the Development of International Law. Eur. J. Int. Law 2009, 20, 922-923.

90. Nader, N.; Arash, M.; Makarand, H.; Aldrich, D.P. Modeling Social Opposition to Infrastructure Development. J. Constr. Eng. Manag. 2014, 140, 4014029. [CrossRef]

91. Cantú-Rivera, H. Business and Human Rights in the Americas: Defining a Latin American Route to Corporate Responsibility. In The Future of Business and Human Rights: Theoretical and Practical Considerations for a UN Treaty; Letnar Cernic, J., Carrillo-Santarelli, N., Eds.; Intersentia: Cambridge, UK, 2018; pp. 163-184. ISBN 9781780686455.

92. Bonnitcha, J.; McCorquodale, R. The Concept of "due Diligence" in the UN Guiding Principles on Business and Human Rights. Eur. J. Int. Law 2017, 28, 899-919. [CrossRef]

93. Lee, J. Nuevo Necaxa-Avila Camacho Highway. In Sustainable Infrastructure in Latin America; Georgoulias, A., Vidaurre-Roche, A.M., Rodriguez, J., Eds.; Harvard University: Cambridge, MA, USA; Inter-American Development Bank: Washington, DC, USA, 2014; pp. 235-259.

94. Comisión Nacional de los Derechos Humanos. Sobre El Caso de La Construcción Del Libramiento de La Autopista México-Cuernavaca, Conocido Como "Paso Exprés" y Posterior Socavón Ocurrido El 12 de Julio de 2017, En Cuernavaca, Morelos Que Derivó En Violaciones a Derechos Humanos de V1 a V7; Comisión Nacional de los Derechos Humanos: Ciudad de Mexico, Mexico, 2018.

95. Secretaría de Medio Ambiente y Recursos Naturales Manifestación de Impacto Ambiental, Modalidad Regional Para El Proyecto "Establecimiento de Bancos de Tiro y Aprovechamiento de Bancos Materiales y Caminos de Acceso Utilizados Para La Formación de Terraplenes y Revestimientos En La Construcción Del Subramo Km 140 + 123 al Km 178+500 de La Autopista Mexico-Tuxpan. Available online: http:/ / sinat.semarnat.gob.mx/dgiraDocs/documentos/pue/estudios/2007/21PU2007V0003.pdf (accessed on 19 April 2020).

96. Secretaría de Comunicaciones y Transportes Titulo de Concesión Necaxa-Tihuatlán. Available online: https://www.sct.gob.mx/ fileadmin/DireccionesGrales/DGDC/Titulos/doctos/56.pdf (accessed on 19 April 2020).

97. Brito, J.L. El Paso de la Muerte de Cuernavaca Entre el Socavón y Más de 100 Victimas Fatales; Proceso: Cuernavaca, Mexico, 2017. 